\title{
Re-remembering the Holocaust in Eastern Europe
}

\author{
Mila Dragojević (D) \\ The University of the South, Sewanee, TN, USA \\ Email:midragoj@sewanee.edu
}

Yellow Star, Red Star: Holocaust Remembrance after Communism, by Jelena Subotić, Ithaca, New York, Cornell University Press, 2019, \$29.95 (hardcover), ISBN 978-1501742408

Jelena Subotić's book is an important contribution to memory studies scholarship because it shows how the mechanism of memory appropriation connects state-led remembrance practices with the processes of national identity formation. Through the comparative analysis of Serbia, Croatia, and Lithuania, Subotić argues that Holocaust remembrance in these states is less about remembering the Holocaust - or acknowledging the states' own responsibilities for the forced displacement and mass killing of the Jewish population on their territories - and more about the political use of the memory of the Holocaust in the context of the postcommunist transition and national identity insecurities. Yellow Star, Red Star, and particularly its chapters on Serbia and Croatia, nicely complement the existing literature - such as the work of Keith Brown, Siniša Malešević, Vjekoslav Perica, Dejan Jović, Emil Kerenji, Vjeran Pavlaković, Jelena Đureinović, Tamara Banjeglav, and Ana Ljubojević, among others - analyzing linkages between nationalism and state-sponsored memorialization practices in the post-Yugoslav states.

One aspect of this book that makes it stand out is the way that Subotic employs stories throughout to personalize diverse perspectives of individuals who are categorized as victims, collaborators, or perpetrators in the literature. This includes the author's own grandfather, who worked in the Special Police in Belgrade under the German occupying administration. This approach goes beyond a standard academic text by adding transparency and a reminder that we are all ultimately responsible for our actions.

The memory of the Holocaust was, as Subotić argues, appropriated - that is, "used to memorialize a different kind of suffering, such as suffering under communism, or suffering from ethnic violence perpetrated by other groups" (p. 9). Rather than denying the Holocaust outright, states strategically altered its memory in ways that minimized or erased local and national history of antifascist resistance. In the case of Serbia, Subotić claims, the memory of the Holocaust was inverted - or "appropriated for discussion of crimes of communism" - and "focused on Croatia's mass murder of ethnic Serbs" (p. 15). One example of the use of the memory of the Holocaust for political mobilization in Serbia was the establishment of the Museum of Genocide in 1992 to shed light on the "crimes against the Serbian people committed in the NDH (Nezavisna država Hrvatska, or Independent State of Croatia)," during the time when Serbian forces were fighting and committing mass atrocities in Croatia and Bosnia (pp. 67-69). In Croatia, the appropriation of the memory of the Holocaust took the form of memory divergence, or "decoupling of the Holocaust from the fascist mass murder of the Serbs" (p. 15). This was, for example, evident in the way that the Jasenovac Memorial minimized the responsibility of the state officials for crimes against Serbs, Jews, and Roma by presenting the state as the "puppet Nazi state" that was obeying the orders of Hitler rather than acknowledging that "the NDH pursued its anti-Serb

\footnotetext{
(C) The Author(s), 2021. Published by Cambridge University Press on behalf of Association for the Study of Nationalities. This is an Open Access article, distributed under the terms of the Creative Commons Attribution licence (https://creativecommons.org/licenses/by/4.0/), which permits unrestricted re-use, distribution, and reproduction in any medium, provided the original work is properly cited.
} 
policies largely autonomously from Nazi Germany" (p. 133). Finally, in Lithuania, memory conflation or the representation of both the Holocaust and the Soviet occupation as genocide - was the dominant form of memory appropriation. The Museum of Genocide/Occupation, which was established in 1992, represented the Soviet occupation as a "genocide" and omitted the mention of the Holocaust until 2011, when it was included in large part as a result of the pressures from abroad (pp. 185-189).

Although the broader theoretical contribution is not entirely new, Subotic resolves one of the theoretical problems that concerns the conflation of the memorialization practices and the processes of identity formation. Scholars of memory studies and nationalism, including Pierre Nora and Benedict Anderson among many others, have theorized about and extensively documented the role of states in the production of memory in the service of national identity formation and the exclusion of perspectives that clashed with the dominant narrative. Subotić adds a new dimension to this literature by identifying and documenting examples of the mechanism - memory appropriation - that actually links the processes of memorialization and national identity formation on the state level in the cases of Serbia, Croatia, and Lithuania in the aftermath of communism. For example, the memorialization of the Semlin concentration camp in Serbia had already been undergoing different transformations throughout the final decade of the dissolving Yugoslav regime (p. 63). Following the collapse of both the political and the economic regime, the Semlin camp became the starting location for the ceremony of the Day of Remembrance for the Victims of Genocide, which replaced "the commemoration of the Holocaust of Serbia's Jews with the commemoration of the Croatian genocide of Serbs” (p. 78). In more recent years, the victimization narrative of "Serbs as Jews" continued in the case of the Semlin camp, as evident in commemorative speeches and the proposed law to create "the Serbian Yad Vashem," which never actually materialized (pp. 78-80). Consequently, we see in this example how the memory of the Holocaust was adjusted and appropriated strategically in the service of nationalist mobilization during the times when state officials faced challenges from the general uncertainties of the regime transition and the international community's charges for human rights violations connected with the state's involvement in regional conflicts.

Another contribution of this book, and also why it is relevant for the interdisciplinary audience, is the addition of a historically grounded theoretical framework. Subotić's explanation is applicable to the identity insecurities - or ontological insecurities - in the postcommunist states during particular historical contexts. These include complex patterns of resistance and collaboration during WWII in all three cases, interethnic political relations in the cases of Serbia and Croatia, and different relationships that these states had with the Soviet Union, among many other historical factors. Such detailed and serious treatment of the key historical moments in the development of the main argument is something that is not very common in the field of international relations because of the disciplinary expectation of scholars to produce an explanation that can be generalized.

In the concluding chapter, Subotić speaks to the political science discipline, too, by including comparative examples of Holocaust memory appropriation in different forms in other European countries. Yet, this material is not nearly as rich and nuanced as the empirical analysis in the chapters on Serbia, Croatia, and Lithuania - and understandably so. In a similar vein, the association of each case with one dominant type of memory appropriation (that is, inversion, divergence, or conflation) provides a neat theoretical framework but also oversimplifies the historical complexity discussed in each case. The examples of memory inversion, conflation, and divergence - in addition to other types of memory appropriation - could be identified in all three cases in various historical periods. For example, some examples of divergence and suppression of the memory of the Holocaust in postwar Lithuania are comparable to the patterns identified in Croatia and Serbia after the 1990s. Perhaps, the introduction of the types of memory appropriation in each case could be useful as a starting point, but this is not essential to the book's main argument, which is that the memory of the Holocaust was used in response to different national identity insecurities these states faced in the aftermath of the collapse of the communist regimes.

One aspect of the argument, in particular, that could have been developed further was the subnational variation in the ways that the memory of the Holocaust was treated. In the case of 
Croatia, Subotic hinted at the regional differences between the parts of the country with more violence in the 1990s, such as Vukovar, and the region of Istria, where WWII monuments were preserved. Perhaps a more systematic examination of these regional differences in all three cases could have been added in order to answer the questions of why and how some commemorative practices and narratives became the dominant ones first locally, and then nationally. This addition would also show the heterogeneity in states' political and societal actors, whose power and ability to influence memorialization practices shifts in response to - or anticipation of - changes in the domestic and international political environment. Nevertheless, by focusing on analyzing power on the national level, Subotić identifies something that three postcommunist states had in common the former communist power-holders who, in their desire to draw support politically and remain in their positions, exaggerated their anticommunist stance in many ways, including in the way that they integrated the memory of the Holocaust into the dominant national narratives.

Yellow Star, Red Star is a valuable book because it identifies and documents different ways in which states appropriate memory. This was the missing link in the existing literature examining the memorialization practices and processes of national identity formation. The careful historical study of the cases of Serbia, Croatia, and Lithuania make this book appealing to interdisciplinary audiences, including the scholars and advanced undergraduate or graduate students of memory studies, nationalism, the Holocaust, Eastern Europe, and political violence. Finally, the powerful stories of diverse experiences throughout the book add a reminder of our responsibility as individuals to protect the memory of the Holocaust and to prevent the formation of the kind of nationalist regimes that aim to exclude people - human beings - simply on the basis of their identities.

Cite this article: Dragojević, M. 2021. Re-remembering the Holocaust in Eastern Europe. Nationalities Papers: 1-3, doi:10.1017/nps.2021.62 